\title{
Formation Mechanisms of Clouds during High-Pressure Conditions in the Coastal Region of Antarctica
}

\author{
By Makoto Wada \\ National Institute of Polar Research, Tokyo 173, Japan \\ (Manuscript received 25 December 1986, in revised form 14 March 1987)
}

\begin{abstract}
Analyzing the aerological data at Syowa Station and the surface data at Syowa and Mizuho Stations Antarctica in 1979, we discuss the mechanism of cloud formation during high-pressure conditions. It was frequently (over 30\%) overcast during high-pressure conditions at Syowa Station except in December, and a similar tendency can be found at Mizuho Station. Moreover, snowfalls were observed at Syowa Station even in these conditions and the frequency of such days was rather larger in winter than in summer. In many cases of high-pressure, a stable layer or an inversion layer was found; some stable layers were around $800 \mathrm{mb}$ level and others were near the ground surface. It was considered that the formation and development of clouds was connected directly with the stable layers. The main mechanisms for forming clouds would be the weak convection in the layer below stable layer or inversion layer, the mixing of cold air with moist air because of wind shear and surface radiative cooling, and for developing clouds would be radiative cooling at the cloud top.
\end{abstract}

\section{Introduction}

In Antarctica a circumpolar anticyclone is often predominant, while cyclones move round over the sea which surrounds the continent and sometimes encroach over the inner land. During high-pressure conditions the air temperature is low and the absolute water vapor content is very small. In spite of these conditions, clouds and precipitation are sometimes observed (Loewe, 1957; Rusin 1961; Orvig, 1970).

Kato (1982), Kato et al. (1977, 1979), and Kato and Higuchi (1979) studied the relationship between $\delta^{18} 0$ of snowfalls and air temperature and the transportation process of water vapor to the antarctic ice sheet. Kato and Higuchi (1979) inferred that water vapor transported into an antarctic anticyclone subsided in it and snow crystals were formed by an isobaric cooling process around a subsidence inversion. However, the mechanism of snowfall in the antarctic anticyclone was not shown in their paper.

Khrgian (1977) reported that stratus clouds were found during weak high-pressure conditions at middle latitudes in Siberia during the transitional period from autumn to winter, but a detailed analysis for them was not shown. Takeda et al. (1982), Kikuchi et al. (1982) and Fujiyoshi et al. (1982) observed precipitating clouds and snow particles in Arctic Canada and they state that precipitation was found not only under lowpressure conditions but also under high-pressure conditions.

Clouds and precipitation in the antarctic anticyclone have often been reported, but their features have not been clearly demonstrated yet. The aim of this paper is to present data on the frequency of appearance of clouds during highpressure conditions and features of the vertical structure of the atmosphere in which they were observed, and also to discuss the processes of their maintenance and development.

\section{Clouds in high-pressure conditions}

As seen in Fig. 1, Syowa Station $\left(69^{\circ} 00^{\prime} \mathrm{S}\right.$, $39^{\circ} 35^{\prime} \mathrm{E}$ ) is situated in the coastal region and Mizuho Station $\left(70^{\circ} 42^{\prime} \mathrm{S}, 44^{\circ} 20^{\prime} \mathrm{E}\right)$ is at a height 


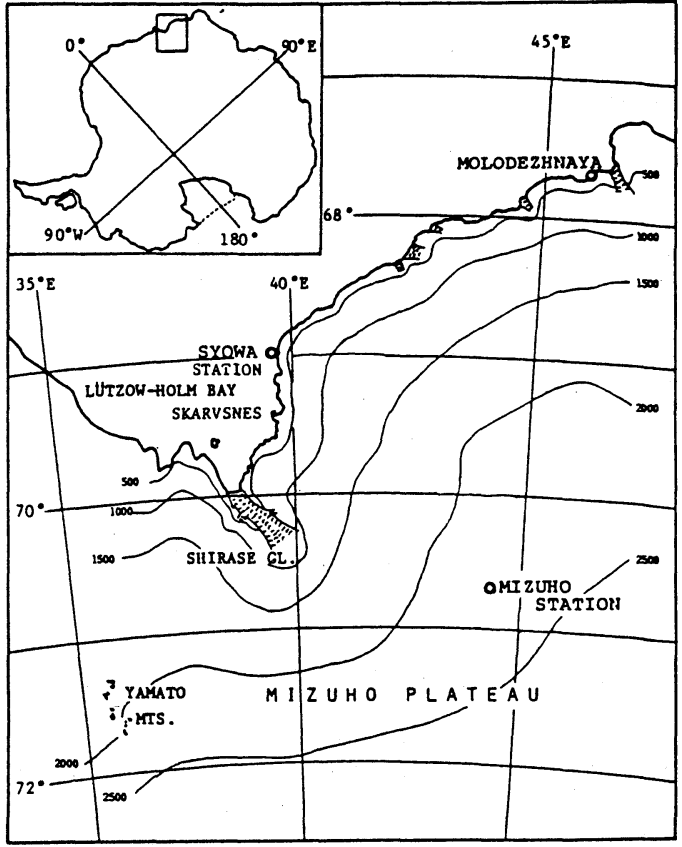

Fig. 1. Locations of Syowa Station and Mizuho Station.

of $2240 \mathrm{~m}$ above sea level in the katabatic wind region. Aerological data were obtained only twice a day at Syowa Station. The data of cloud amount and the number of snowfall days at these stations in 1979 (the period of Polar Experiment; POLEX-South) are used together with aerological data (Japan Meteorological Agency, 1981) in the present analysis. Cloud amount is generally larger at Syowa Station than Mizuho Station and a circumpolar anticyclone is less predominant at Syowa Station.

It is rather difficult to define high-pressure conditions precisely. It is defined here that each station was in high-pressure conditions at time $t_{0}$ if $\delta^{2} p\left(t_{0}\right)$ expressed by the following equation was less than $-1 \mathrm{mb}$, and that each station was in low-pressure conditions at time $t_{0}$ if $\delta^{2} p$ $\left(t_{0}\right)$ was larger than $1 \mathrm{mb}$;

$$
\begin{aligned}
\delta^{2} p\left(t_{0}\right)= & p\left(t_{0}+6 \text { hours }\right)+p\left(t_{0}-6 \text { hours }\right)- \\
& 2 p\left(t_{0}\right)
\end{aligned}
$$

where $p(t)$ is surface pressure (mb) at time $t$.

Table 1 shows monthly frequencies at which each station was in high-pressure conditions or low-pressure conditions. Table 2 gives monthly
Table 1. Monthly frequencies of high-pressure conditions $(\mathrm{H})$ and low-pressure conditons (L) at Syowa Station and Mizuho Station

\begin{tabular}{llllll}
\hline & \multicolumn{2}{c}{ Syowa } & & \multicolumn{2}{c}{ Mizuho } \\
\cline { 2 - 3 } \cline { 6 - 6 } & \multicolumn{1}{c}{$\mathrm{H}$} & $\mathrm{L}$ & & $\mathrm{H}$ & $\mathrm{L}$ \\
\hline January & $24(\%)$ & $23(\%)$ & & $20(\%)$ & $20(\%)$ \\
February & 22 & 19 & & 12 & 15 \\
March & 26 & 19 & & 12 & 12 \\
April & 21 & 23 & & 12 & 19 \\
May & 26 & 22 & & 20 & 20 \\
June & 28 & 28 & & 24 & 23 \\
July & 35 & 33 & & 24 & 24 \\
August & 37 & 31 & & 27 & 31 \\
September & 29 & 20 & & 19 & 19 \\
October & 32 & 27 & & 13 & 20 \\
November & 33 & 30 & & 21 & 22 \\
December & 16 & 18 & & 8 & 10 \\
\hline
\end{tabular}

Table 2. Monthly frequencies of cloudless days and overcast days during high pressure conditions at each stations.

\begin{tabular}{lccccc}
\hline & \multicolumn{2}{c}{ Syowa } & & \multicolumn{2}{c}{ Mizuho } \\
\cline { 2 - 3 } \cline { 5 - 6 } & 0 & 10 & & 0 & 10 \\
\hline January & $16(\%)$ & $43(\%)$ & & $17(\%)$ & $55(\%)$ \\
February & 8 & 36 & & 0 & 60 \\
March & 6 & 75 & & 27 & 36 \\
April & 20 & 48 & & 0 & 72 \\
May & 34 & 41 & & 31 & 47 \\
June & 24 & 41 & & 45 & 27 \\
July & 25 & 50 & & 54 & 36 \\
August & 19 & 50 & & 32 & 40 \\
September & 37 & 34 & & 35 & 29 \\
October & 35 & 33 & & 50 & 17 \\
November & 13 & 58 & & 15 & 52 \\
December & 70 & 1 & & 14 & 28 \\
\hline
\end{tabular}

frequencies of cloudless days (cloud amount is zero) and overcast day (cloud amount is ten) at each station during high-pressure conditions. The data at $03.00,09.00,15.00$ and 21.00 LST were used in these tables, though the data at 03.00 LST were not used at Mizuho Station. Each station experiences the high-pressure conditions with a frequency of about $20 \%$ and both stations, especially Syowa Station, tend to more frequently encounter the high-pressure conditions in winter than in summer. During high-pressure conditions it was frequently overcast at Syowa Station except in December, and a similar tendency can be found at Mizuho Station, too, though the tendency is not so clear as at Syowa Station. 

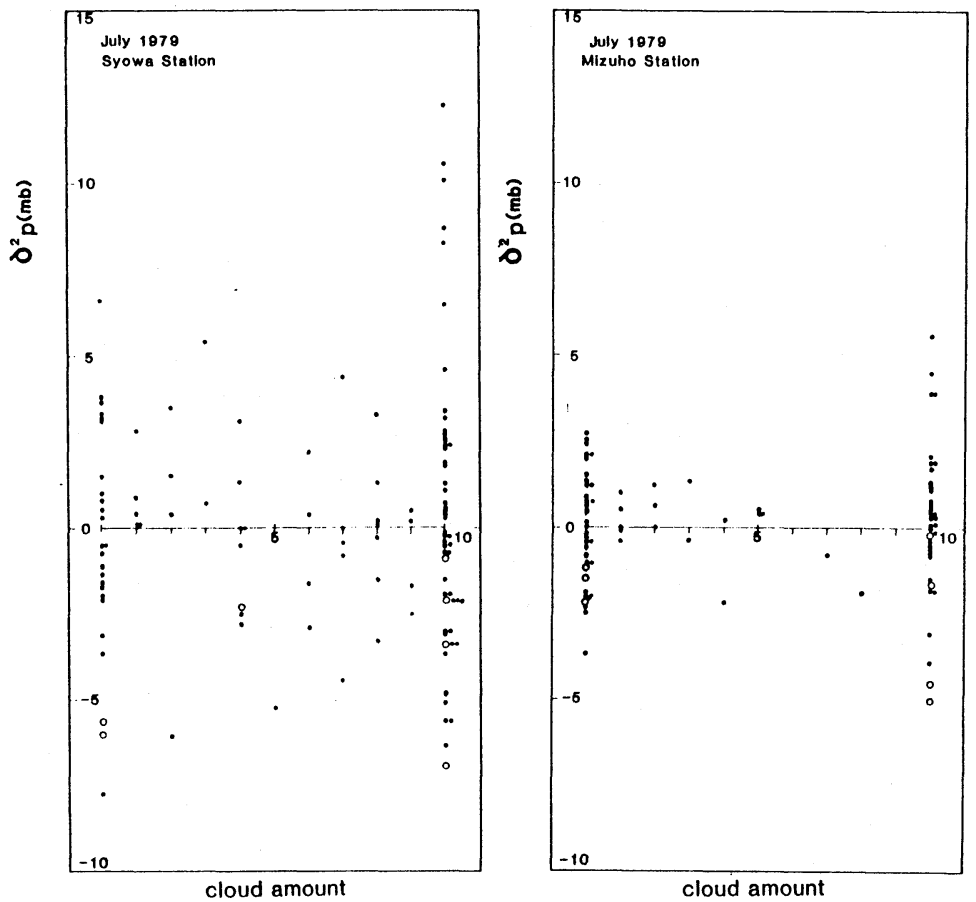

Fig. 2. Relationships between cloud amount and $\delta^{2} p$ at Syowa Station and Mizuho Station.

The relationship between cloud amount and $\delta^{2} p$ in July is plotted in Fig. 2. Open circles denote the data which showed the maximum peaks in the time series of surface pressure. Cloudy days, even days of complete overcast, are evident in spite of the condition $\delta^{2} p<-1$, especially at Syowa Station. The values of $\delta^{2} p$ at Syowa Station when snowfalls were reported are shown in Fig. 3. It is recognized that snowfalls were observed even in the high-pressure conditions $\left(\delta^{2} p\right.$ $<-1$ ), though snowfalls were found more frequently in the low-pressure conditions $\left(\delta^{2} p>1\right)$. Thus it is demonstrated that clouds and snowfalls were often observed during high-pressure conditions at Syowa Station.

The frequency of the high-pressure conditions over Syowa Station or Mizuho Station was greater in winter than in summer, as shown in Table 1 . The reason is that a circumpolar anticyclone is stronger in winter than in summer. Figure 3 indicates that the frequency of snowfall days during high-pressure conditions was $22 \%$ in summer, $28 \%$ in the transitional season and $33 \%$ in winter. The frequency of complete overcast under high-pressure conditions was $36 \%$ in July

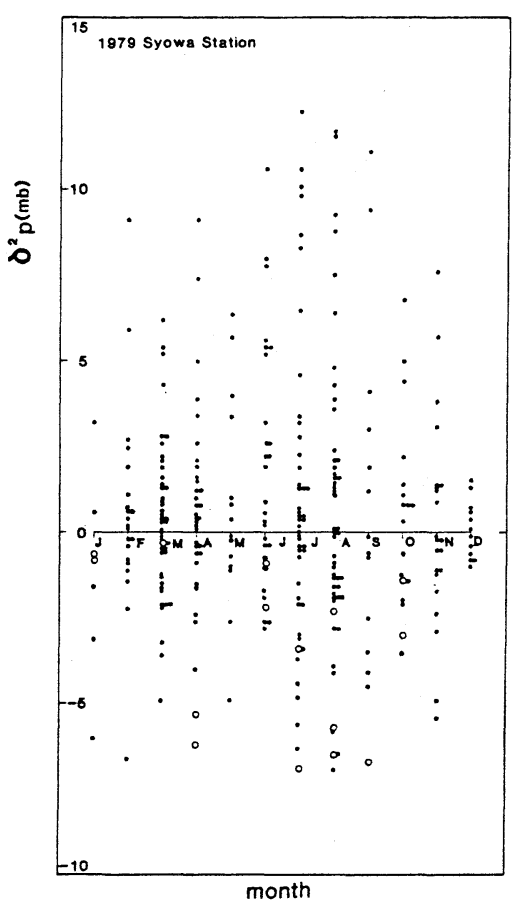

Fig. 3. $\delta^{2} p$ in cases of snowfall at Syowa Station. 
and $30 \%$ in January. These results suggest that the frequency of snowfall days or cloudy days during high-pressure conditions was rather larger in winter than in summer.

\section{Typical weather patterns during the high- pressure conditions}

When Syowa Station was experiencing highpressure, most weather patterns could be classified into two types as shown in Fig. 4. A: Syowa Station was covered with the southern highpressure and B: Syowa Station was covered with the northern high-pressure.

A consideration of the records of surface pressure shows that Syowa Station experienced 100 periods of high-pressure in 1979. However, weather charts indicate that a small cyclone or a front was observed near Syowa Station even on
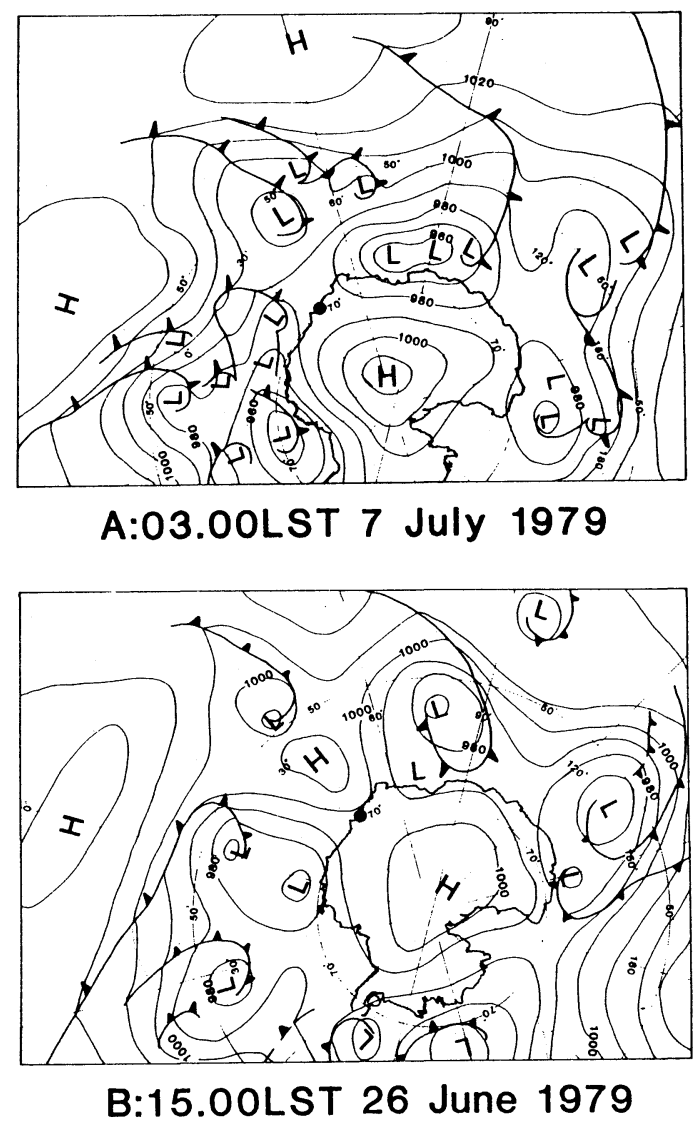

Fig. 4. Typical weather patterns A and B during highpressure conditions at Syowa Station (solid circle). some of these occasions. An examination of weather charts revealed 22 cases as being clear high-pressure events. These cases are listed in Table 3. The period of each case is taken to be the time from one pressure minimum to the next pressure minimum. The weather pattern A in Fig. 4 is often observed in winter, and pattern B is more often seen in summer. Cloud amounts at the time of maximum surface pressure are shown in the fifth column (N) of Table 3. However, it does not always follow that a cloud amount of 0 means no cloud through the period of the case. In 13 cases clouds were reported at the time of maximum surface pressure.

\section{Vertical structure of the atmosphere in an individual cloudy case}

Upper air soundings have been carried out at Syowa Station since 1959. The data of air temperature and relative humidity in 1979 were used in the present analysis. A stable layer or an inversion layer was found in many cases of the high pressure for both weather patterns $\mathrm{A}$ and $\mathrm{B}$. Some stable layers were around $800 \mathrm{mb}$ level and the others were near the surface. Below, we will describe the characteristic features of a vertical structure of the cloudy atmosphere in typical cases, paying attention to the stable layer.

It is a difficult problem of how to define a cloud layer solely from data of upper air soundings. Figure 5 shows the relationship between the highest value of the vertical profile of relative humidity with respect to water and the appearance of clouds in above-mentioned 22 cases. The abscissa is air temperature at the level of the highest humidity. Black circles mean that the cloud amount is 9 or 10 at that time and crosses mean that the cloud amount is 0 or 1 . Data for the other values of cloud amount are not shown in the figure. A solid line indicates saturation with respect to ice. A dashed line indicates a relative humidity of $75 \%$. In most of cases in which clouds were observed at Syowa Station with a cloud amount of 9 or 10 , the highest relative humidity exceeds $75 \%$ except when the air tempeature is below $-25^{\circ} \mathrm{C}$. When the cloud amount is 0 or 1 , the highest relative humidity is less than $75 \%$ except for a few cases. On the basis of the results in Fig. 5, even though these results are not direct evidence of cloud 
Table 3. Classification of 22 cases. S, W and T mean summer (January, February, March, December), winter (June, July, August, September) and transitional season (April, May, October, November), respectively. S, N, $\max R H$ and $Z$ on the first line refer to season, cloud amount, the maximum relative humidity and height of "cloud layer", respectively. When the maximum relative humidity is lower than $75 \%, \mathrm{Z}$ shows the height of the maximum relative humidity level.

\begin{tabular}{rcrrrrc}
\hline Case No. & \multicolumn{1}{c}{ period } & $\mathrm{S}$ & $\mathrm{N}$ & $\begin{array}{c}\max \mathrm{RH} \\
(\%)\end{array}$ & $\begin{array}{c}\mathrm{Z} \\
(\mathrm{mb})\end{array}$ \\
\hline $\mathrm{A}$ & 2 & 15.00LST 13-15.00LST 17 January & $\mathrm{S}$ & 10 & 67 & 700 \\
3 & 03.00LST 20-03.00LST 24 February & $\mathrm{S}$ & 1 & 70 & 890 \\
5 & 03.00LST 10-15.00LST 13 March & $\mathrm{S}$ & 10 & 81 & $880-940$ \\
7 & 03.00LST 15-15.00LST 18 June & $\mathrm{W}$ & 0 & 53 & 810 \\
9 & 03.00LST 5-03.00LST 9 July & $\mathrm{W}$ & 10 & 82 & $770-855$ \\
10 & 15.00LST 9-15.00LST 12 July & $\mathrm{W}$ & 0 & 61 & 990 \\
11 & 03.00LST 13-15.00LST 15 July & $\mathrm{W}$ & 0 & 56 & 765 \\
12 & 03.00LST 17-03.00LST 22 July & $\mathrm{W}$ & 10 & 77 & $695-715$ \\
13 & 15.00LST 20-15.00LST 23 August & $\mathrm{W}$ & 7 & 78 & $880-990$ \\
14 & 03.00LST 11-15.00LST 14 September & $\mathrm{W}$ & 4 & 61 & 850 \\
15 & 15.00LST 18-03.00LST 21 September & $\mathrm{W}$ & 0 & 55 & 985 \\
16 & 15.00LST 21-03.00LST 27 September & $\mathrm{W}$ & 0 & 76 & 975 \\
17 & 03.00LST 5-15.00LST 7 October & $\mathrm{T}$ & 0 & 41 & 1000 \\
20 & 15.00LST 11-15.00LST 16 October & $\mathrm{T}$ & 1 & 70 & 850 \\
B & 15.00LST 5-03.00LST 8 January & $\mathrm{S}$ & 10 & 89 & $930-990$ \\
4 & 15.00LST 24-03.00LST 28 February & $\mathrm{S}$ & 10 & 85 & $670-995$ \\
6 & 03.00LST 23-03.00LST 26 April & $\mathrm{T}$ & 0 & 59 & 845 \\
8 & 15.00LST 23-03.00LST 28 June & $\mathrm{W}$ & 4 & 78 & $875-905$ \\
18 & 15.00LST 17-15.00LST 20 October & $\mathrm{T}$ & 10 & 67 & 815 \\
19 & 15.00LST 20-15.00LST 22 October & $\mathrm{T}$ & 10 & 78 & $550-655$ \\
21 & 03.00LST 4-15.00LST 7 December & $\mathrm{S}$ & 0 & 72 & 845 \\
22 & 15.00LST 11-03.00LST 15 December & $\mathrm{S}$ & 0 & 72 & 1005 \\
\hline
\end{tabular}

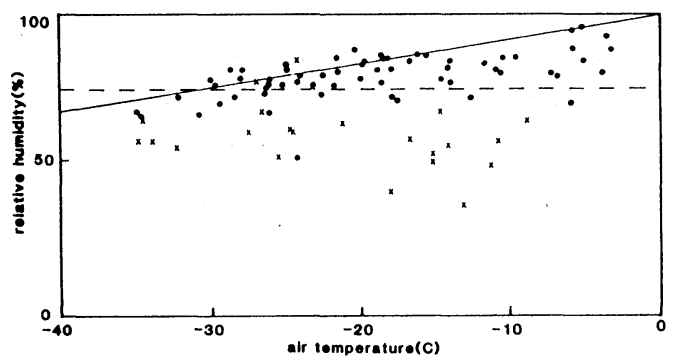

Fig. 5. Relationship between air temperature and relative humidity at the level of the highest relative humidity. Black circles and crosses refer to cloud amounts of 9 or 10 and cloud amounts of 0 or 1 , respectively.

layers, the layer of higher relative humidity than $75 \%$ is regarded as implying the existence of clouds and it is called a "cloud layer" in this paper. A "cloud layer" defined in this way is shown in Table 3. These "cloud layers" are classi- fied as a low- or middle-level "cloud layer" and one low-level layer near the surface.

\section{(1) Low- or middle-level "cloud layer" Case 9 (5 to 9 July)}

There were some cloudy cases in the weather pattern A. Case 9 is selected as a typical case. As shown in Fig. 6a, cloud amount diminished to zero at 03.00 LST on the 6 th and then it increased until 03.00 LST on the 7th. Surface pressure continued to increase from 09.00 LST on the 5 th and reached the maximum value at 21.00 LST on the 7 th. Cloud amount remained large while surface pressure was high.

The ascent curves of potential temperature $(\theta)$, relative humidity $(\mathrm{RH})$ and the mixing ratio (r) of water vapor at Syowa Station are shown in Fig. 6b. A very stable layer (hatched layer) was observed between $735 \mathrm{mb}$ and $865 \mathrm{mb}$ levels in Fig. 6b-(1). The layer where the lapse rate of 
potential temperature is larger than $0.07 \mathrm{~K} / \mathrm{mb}$ is defined as a very stable layer in this paper. The altitude above $840 \mathrm{mb}$ level in this layer was dry. The lapse rate of temperature was nearly moist adiabatic below this stable layer. Although a relative humidity higher than $75 \%$ was not observed, visible clouds would have existed around $900 \mathrm{mb}$ level where the highest relative humidity was found.

Two very stable layers are recognized in Fig. $6 b-(3)$. The mixing ratio of water vapor was high in the lower stable layer and a dry layer can be found above the upper stable layer. In Fig. 6b-(2) a dry layer can be also found above the very stable layer. These dry layers would have been

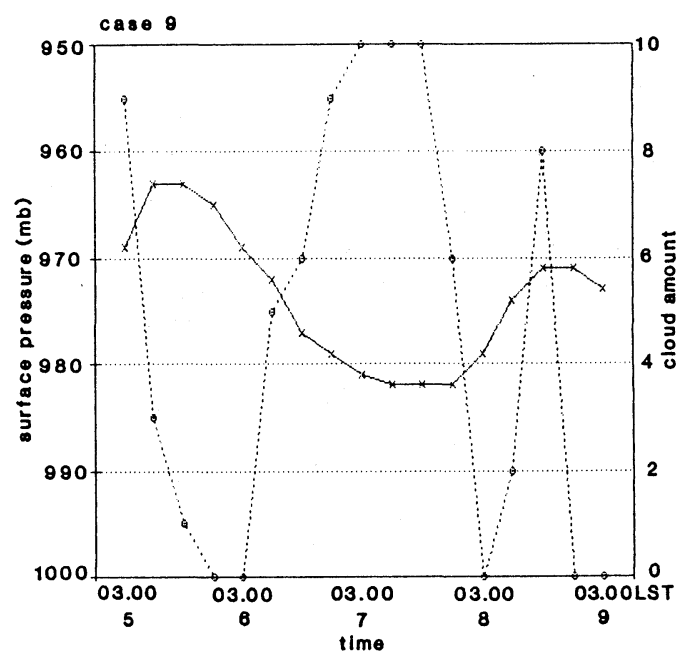

(a) formed by the subsidence of air during high-pressure conditions. A "cloud layer" was found in Figs. 6b-(2) and -(3).

There is a layer where relative humidity decreased rapidly with height above the level of the maximum relative humidity in all observations shown in Fig. $6 \mathrm{~b}$. Table 4 shows the height of the base of this layer (hereafter described as the "base") and also the air temperature and the mixing ratio of water vapor at the "base". Most of the "bases" were observed near the base of the very stable layers. The highest "base" (775 mb level) was found in Fig. 6b-(3). It seems that the subsidence of the atmosphere became relatively weak in spite of the fact that maximum pressure was observed on the ground at 15.00 LST on the 7th. The "base", shown in Fig. 6b(4), became lower again at 03.00 LST on the 8th. If the air at the $775 \mathrm{mb}$ level at 15.00 LST on the 7 th, subsided adiabatically to the $825 \mathrm{mb}$ level, its temperature can be estimated to be $-26.6^{\circ} \mathrm{C}$ which is in good agreement with the temperature at the $825 \mathrm{mb}$ level at $03.00 \mathrm{LST}$ on the 8 th. The height of the "base" would have been controlled by the strength of the subsidence and the activity of vertical mixing at low levels.

As shown by the profile of relative humidity in Fig. 6b-(3) the "cloud layer" was found between $770 \mathrm{mb}$ and $860 \mathrm{mb}$ levels. However, a "cloud layer" was not found in the profile of relative humidity in Fig. 6b-(4) and clouds were not reported by visual observation at this time. The "cloud layer" increased with the ascent of

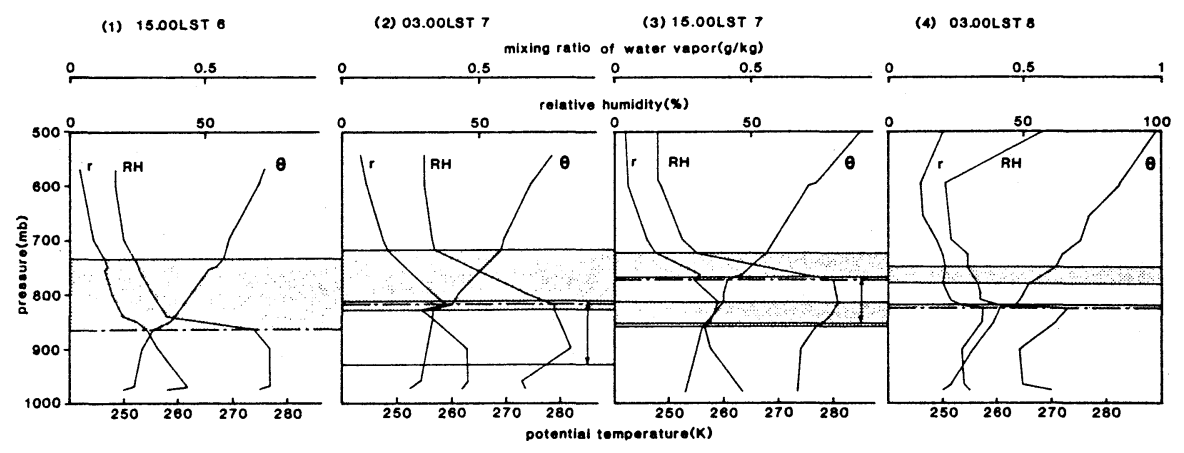

(b)

Fig. 6. Case 9. a: Surface pressure (solid line with crosses) and cloud amount (dotted line with circles) at Syowa Station. b: Ascent curves of potential temperature, relative humidity and the mixing ratio of water vapor at Syowa Station. Hatched layers and layers with arrows indicate very stable layers and cloud layers. Chain-lines show the levels of "bases". 
Table 4. Height (pressure), air temperature and the mixing ratio of water vapor at the "base" in the Case 9.

\begin{tabular}{lccc}
\hline & height $(\mathrm{mb})$ & temperature $\left({ }^{\circ} \mathrm{C}\right)$ & mixing ratio $(\mathrm{g} / \mathrm{kg})$ \\
\hline 15.00LST 6 July & 863 & -28.1 & 0.29 \\
03. 00LST 7 July & 818 & -27.5 & 0.38 \\
15.00LST 7 July & 775 & -31.0 & 0.29 \\
03. 00LST 8 July & 825 & -26.5 & 0.35 \\
\hline
\end{tabular}

the "base" and the "cloud layer" dissipated in association with its descent. Such an evolution was found frequently in weather pattern $\mathrm{A}$ and sometimes in weather pattern B. It can be said that the "base" corresponds roughly to the top of the "cloud layer".

The profile of relative humidity in Fig. 6b-(2) shows that the "cloud layer" developed even above the base of the inversion layer. In Fig. 6b(3) two very stable layers were seen and the "cloud layer" was found between $770 \mathrm{mb}$ and $860 \mathrm{mb}$ levels. Namely, the "cloud layer" spread out through and above the lower stable layer. These facts suggest that radiative cooling at the cloud top assisted the vertical development of the cloud. Cases 2, 5 and 18 in Table 3 indicate the vertical structure of the atmosphere around a "cloud layer" which is similar to that in Case 9.

\section{Case 8 (23 to 28 June)}

In Case 8 of weather pattern $\mathrm{B}$, the relative humidity was slowly decreasing with height above the level of maximum relative humidity, the $880 \mathrm{mb}$ level. The maximum of surface pressure appeared at 15.00 LST on the 26th when the cloud amount was 4 . Cloud amounts at 03.00 LST on the 26th and 27 th were 0.

Figure 7 a shows the vertical profiles of potential temperature, relative humidity and mixing ratio of water vapor at 15.00 LST on the 26 th. The vertical gradient of relative humidity in the layer above the $880 \mathrm{mb}$ level is fairly small in comparison with Case 9. The maximum value of the mixing ratio of water vapor and relative humidity were seen at the top of a very stable layer.

At Syowa Station, northeasterly winds are often predominant in the layer near surface. Figure $7 \mathrm{~b}$ shows wind profiles at 03.00 LST and 15.00 LST on the 26th and 03.00 LST on the
15.00LST 26 June

(a)
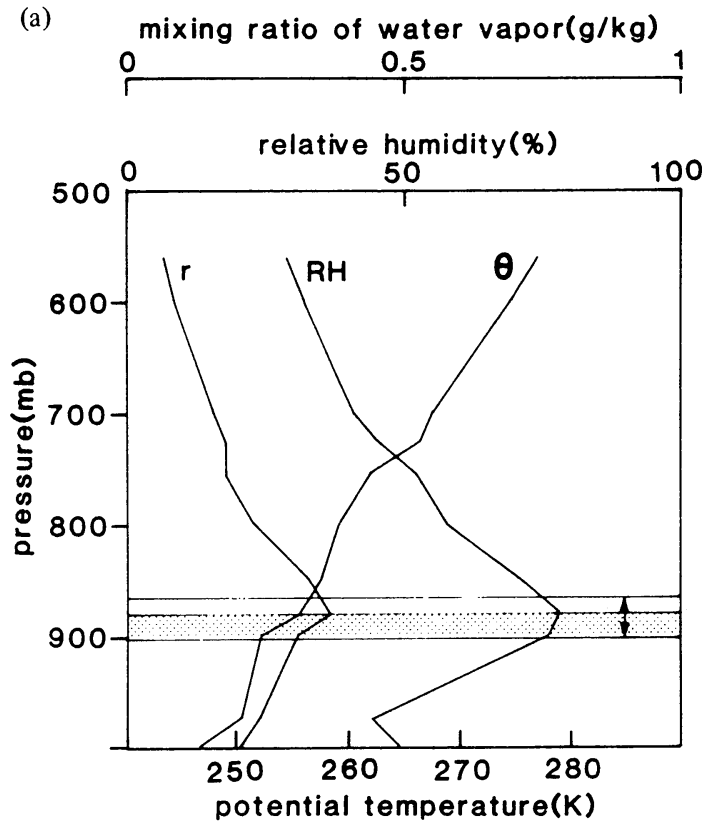

(b)

(1)

(2)

(3)

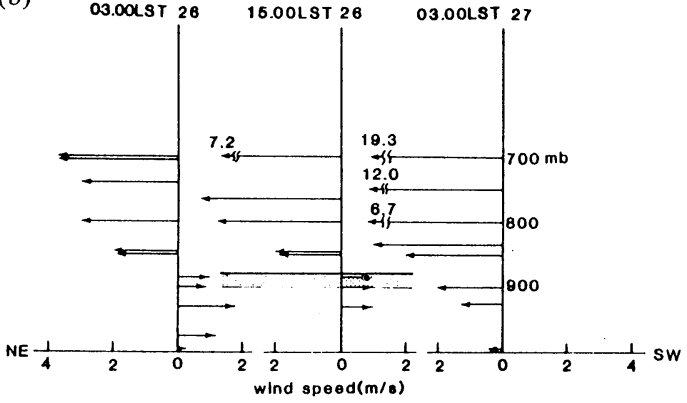

Fig. 7. Case 8. a: Ascent curves of potential temperature, relative humidity and the mixing ratio of water vapor at Syowa Station at 15.00 LST on the 26th June. Hatched layer and layer with arrow denote a very stable and a cloud layer, respectively. b: Wind profiles in the NE-SW direction at $03.00 \mathrm{LST}$ and 15.00 LST on 26 June and 03.00 LST on 27 June. The hatched area indicates a very stable layer. The thick solid line means the level of maximum relative humidity. 
27 th in the direction from northeast to southwest. As shown in Fig. 7b-(1) and -(2), northeasterly winds blew in the layer below $885 \mathrm{mb}$ level and southwesterly winds blew in the layer above $885 \mathrm{mb}$ level. However, winds had a southwest component through the layer between the surface and the $700 \mathrm{mb}$ level, as shown in Fig. $7 \mathrm{~b}-(3)$. The potential temperature at the $900 \mathrm{mb}$ level at the time shown in Fig. 7b-(2) was lower than those at the times shown in Fig. 7b-(1) and -(3), although the potential temperature at the $850 \mathrm{mb}$ level was nearly constant. Northeasterly winds in the layer below the $885 \mathrm{mb}$ level caused the decrease of potential temperature around the $900 \mathrm{mb}$ level and the mixing of cold air with moist air would have resulted in the increase of relative humidity. Vertical structures of the atmosphere in Cases 6, 7 are similar to this case. However, in spite of the relative humidity increase, it did not exceed $75 \%$ in Cases 6 and 7.

\section{Case 19 (20 to 22 October)}

In Case 19 of weather pattern B, a very stable layer was recognized at middle levels and a layer of relative humidity larger than $75 \%$ was found between the $550 \mathrm{mb}$ and $655 \mathrm{mb}$ levels at 03.00 LST on the 21 st. Figure 8 a shows the cloud amount and surface pressure at Syowa Station during the period from 15.00 LST on the 20th to 15.00 LST on the $22 \mathrm{nd}$. The cloud amount was 10 at 03.00 LST on the 21 st when surface pressure showed a maximum value, although the cloud amount was 0 at 15.00 LST on the 20th and the $21 \mathrm{st}$. The profile of wind components in the direction from northeast to southwest at 03.00 LST on the 21 st is shown in Fig. $8 \mathrm{~b}$. Strong southwesterly winds blew in the moist layer in this figure. Very strong west-southwesterly winds blew persistently at middle and upper levels on the 20th and 21st. Water vapor in the moist layer was supplied by strong winds at middle levels. The vertical structures of the atmosphere in Cases 12 and 14 are similar to this case.

\section{(2) "Cloud layer" near the surface}

\section{Case 16 (21 to 27 September)}

As shown in Fig. 9, an inversion layer was found at low levels at 03.00 LST on the 23rd. Ice fog was observed a few times from 03.00 LST on the 22 nd to $15.00 \mathrm{LST}$ on the $23 \mathrm{rd}$. An inversion

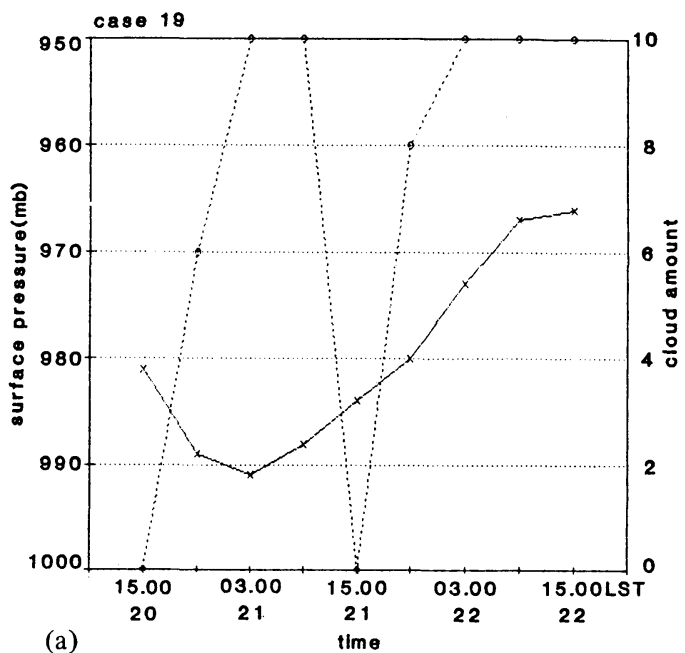

(a)

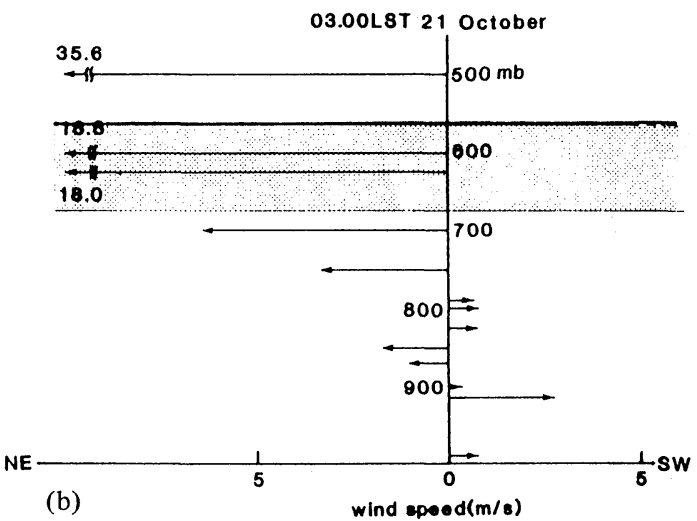

Fig. 8. Case 19. a: Surface pressure (solid line with crosses) and cloud amount (dotted line with circles) at Syowa Station. b: Wind profile in the NE-SW direction at 03.00 LST on 21 October. The hatched area means a very stable layer. The thick line indicates the level of maximum relative humidity.

layer at low levels was often found in weather pattern $\mathbf{A}$ and ice fog was often observed in this situation. The relative humidity at low levels would have increased as a result of the cooling of the air due to the contact with the cold snow surface, and ice fog or clouds would have been formed at low levels. This type of a cloud was optically very thin and it was not reported as a cloud sometimes (cloud amount was zero at 03.00 LST on the 23rd). Case 20 is similar to Case 16 as far as the structure of the atmosphere is concerned.

\section{Case 1 ( 5 to 8 January)}

In Case 1 of weather pattern $B$, an inversion 


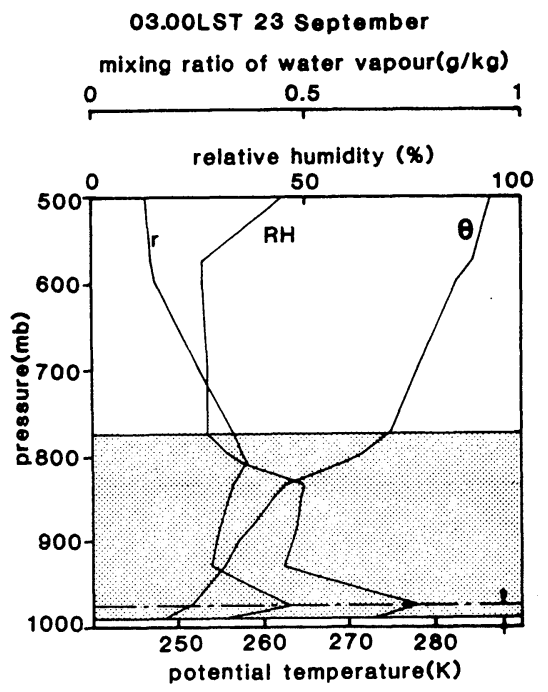

Fig. 9. Case 16. Ascent curves of potential temperature, relative humidity and the mixing ratio of water vapor at Syowa Station at 03.00 LST on 23 September. A layer between arrows denotes an inversion layer.

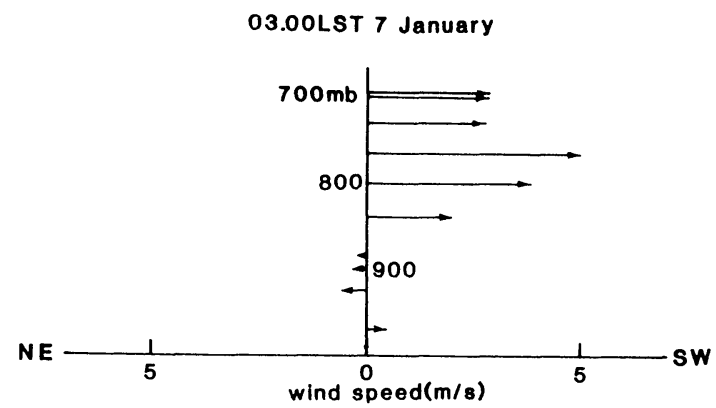

Fig. 10. Case 1. Wind profile in the NE-SW direction at 03.00 LST on 7 January.

Table 5. Cloud amount, relative humidity and air temperature at surface in Case 1.

\begin{tabular}{lccc}
\hline & cloud amount & $\begin{array}{c}\text { relative huuidity } \\
(\%)\end{array}$ & $\begin{array}{c}\text { temperature } \\
\left({ }^{\circ} \mathrm{C}\right)\end{array}$ \\
03.00LST 6 January & 10 & 72 & -6.3 \\
15.00LST 6 January & 4 & 64 & -3.7 \\
03.00LST 7 January & 10 & 88 & -6.2 \\
15.00LST 7 January & 7 & 82 & -3.8 \\
03.00LST 8 January & 10 & 93 & -6.3 \\
15.00LST 8 January & 10 & 83 & -5.0 \\
\hline
\end{tabular}

layer was found near the surface. Cloud amount, relative humidity and air temperature at the surface during the period from the 6 th to the 8 th were shown in Table 5 . The cloud amount at 03.00 LST was ten on all three days and that at 15.00 LST was smaller except at 15.00 LST on the 8 th. On these days relative humidities and air temperatures at 03.00 LST were higher and lower than those at 15.00 LST respectively. This fact suggests that air containing much water vapor was cooled by radiative cooling at the surface and a cloud or fog layer was formed near the surface. Figure 10 shows the wind profile in the direction from northeast to southwest at 03.00 LST on the 7th when the maximum surface pressure was recorded. Southwesterly winds were found below the $850 \mathrm{mb}$ level and northeasterly winds, which are usually predominant near the surface, blew between the $850 \mathrm{mb}$ and $700 \mathrm{mb}$ levels. Water vapor which was associated with the formation of clouds would have been supplied by southwesterly winds at low levels. Case 22 is similar to this case as far as the structure of the atmosphere around a "cloud layer" is concerned.

\section{Discussion}

According to Table 3, weather pattern A was observed more frequently in winter, and pattern B more frequently in summer. In the 22 cases analyzed, 14 cases were of pattern A and 8 cases were of pattern B. The "base" was seen in 8 cases of pattern A (Cases 2, 3, 5, 9, 11, 16, 17 and 20) and one case of pattern B (Case 18). Clouds were observed in 4 cases and no cloud 
was reported in 5 cases. In order to study the following relationship between the atmosphere below the "base" and the appearance of clouds in these 9 cases, $\Delta 0$ and $\bar{r}$ were introduced;

$$
\begin{aligned}
\Delta \theta & =\left(\theta\left(z_{1}\right)-\theta\left(z_{2}\right)\right) /\left(z_{2}-z_{1}\right) \times 100, \\
\bar{r} & =\left(r\left(z_{1}\right)+r\left(z_{2}\right)\right) / 2,
\end{aligned}
$$

where $z_{1}$, and $z_{2}$ are pressures at the "base" and surface, respectively. A larger $\Delta 0$ means that the layer is more stable and a larger $\bar{r}$ means that the air in the layer contains more water vapor.

In Fig. 11, $\Delta 0$ is larger than 5 in the case of no cloud except for one case and $\Delta 0$ is smaller than 5 in cloudy cases, in spite of the water vapor content. The stability, that is to say, the strength of upward motion of air in the layer between the "base", which was around $800 \mathrm{mb}$, and the surface would have been related to the formation of clouds.

Now we selected seven cases in which the cloud amount increased between successive observation times and the "base" was seen at both observation times. These are shown in Table 6 . In the fifth column the gradient of potential temperature $(\delta \theta)$ in the layer just above the "base" is shown. The values of $\delta \theta$ are larger in cloudy conditions than in cloudless ones, except for Number 6 in Table 6, and cloud amount increased from 15.00 LST to 3.00 LST except for

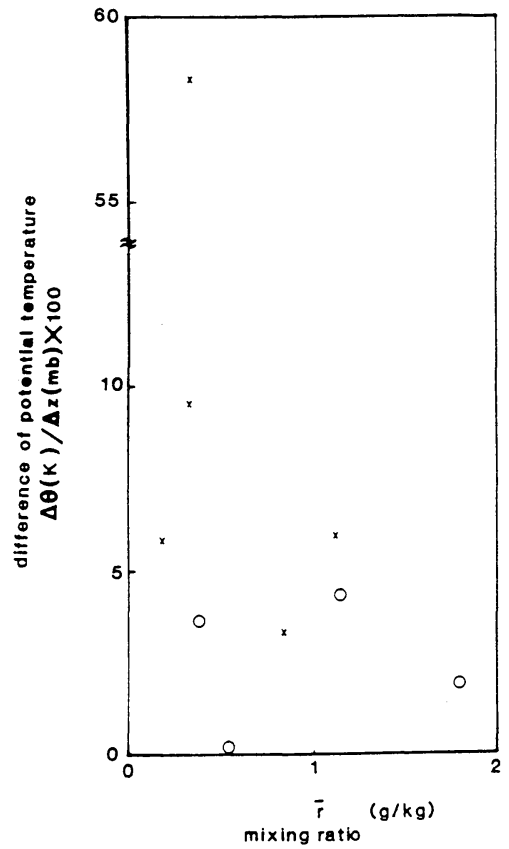

Fig. 11. The differences of potential temperature and the mean mixing ratio of water vapor between the "base" and surface. Circles and crosses denote the data on cloudy days and the data on cloudless days, respectively.

Number 6 in Table 6. It is very difficult to decide on the height of cloud top from aerological data. But it would be reasonable to say that when a

Table 6. Height in mb, potential temperature $(\theta)$ and the gradient of potential temperature $(\delta \theta)$ of the "base"

\begin{tabular}{|c|c|c|c|c|c|}
\hline Number & time & $\begin{array}{c}\text { height } \\
(\mathrm{mb})\end{array}$ & $\begin{array}{c}\theta \\
(\mathrm{K})\end{array}$ & $\begin{array}{c}\delta \theta \\
(\mathrm{K} / 100 \mathrm{mb})\end{array}$ & clouds \\
\hline \multirow[t]{2}{*}{1} & 15.00LST 14 January & 794 & 280.2 & 7.2 & $0^{+} \mathrm{Ac}, 0^{+} \mathrm{Ci}$ \\
\hline & 03.00LST 15 January & 714 & 281.1 & 25.7 & $10^{-} \mathrm{Ac}$ \\
\hline \multirow[t]{2}{*}{2} & 15.00LST 17 June & 900 & 255.1 & 5.7 & - \\
\hline & 03.00LST $18 \mathrm{June}$ & 885 & 255.0 & 12.5 & $0^{+} \mathrm{Ac}$ \\
\hline \multirow[t]{2}{*}{3} & 15.00LST 27 June & 661 & 273.9 & 3.1 & - \\
\hline & 03.00LST 27 June & 639 & 275.1 & 25.0 & $7 \mathrm{As}, \mathrm{xAc}$ \\
\hline \multirow[t]{2}{*}{4} & 15.00LST 6 July & 867 & 255.3 & 19.4 & $6 \mathrm{Ac}, 2 \mathrm{Ci}$ \\
\hline & 03.00LST 7 July & 831 & 256.3 & 30.0 & $10 \mathrm{As}$ \\
\hline \multirow[t]{2}{*}{5} & 15.00LST 14 July & 700 & 274.9 & 5.9 & $0^{+} \mathrm{Ac}, 10^{-} \mathrm{Ci}$ \\
\hline & 03.00LST 15 July & 700 & 274.6 & 8.9 & $7 \mathrm{Ac}, \mathrm{xCi}$ \\
\hline \multirow[t]{2}{*}{6} & 15.00LST 18 July & 877 & 258.9 & 15.2 & $0^{+} \mathrm{Ac}$ \\
\hline & 03.00LST 19 July & 872 & 260.7 & 12.4 & $10 \mathrm{As}$ \\
\hline \multirow[t]{2}{*}{7} & 15.00LST 18 October & 800 & 269.9 & 7.1 & $1 \mathrm{Ci}$ \\
\hline & 03.00LST 19 October & 753 & 269.0 & 20.0 & $0+\mathrm{Sc}, 8 \mathrm{Ac}$ \\
\hline
\end{tabular}
and clouds. 
cloud is formed, it will be below a very stable layer, as Kikuchi et al. (1976) observed using two fish-eye-lens cameras that cloud-top level was below a stable layer. The "base" is near the base of that layer. Table 6 suggests that after clouds were formed, the gradient of potential temperature near the cloud-top became larger and cloud amount increased. Some authors (Stephens et al., 1978; Lilly and Schubert, 1980; etc.) have discussed radiative cooling of a cloudtopped layer. In Antarctica, upward longwave radiation of a cloud-topped layer occurs efficiently because there is little water vapor above the layer, and downward shortwave radiation is much reduced during polar night. Radiative cooling can be expected to have a large influence on the maintenance and development of clouds in cases where the motion of air during high-pressure conditions is weak.

Another important mechanism of cloud formation is the mixing of cold air with moist air. The maximum humidity layer was formed between a lower cold layer and an upper moist layer. The wind direction in the layers was opposed. Vertical motion of air therefore occurs and air becomes mixed due to eddy diffusion across the maximum humidity layer. However, a thick cloud will rarely be formed, according to the observations of cloud amount and cloud thickness in Cases 6,7 and 8. The "base" was not as clearly formed in these cases as in Case 8.

There were four cases $(1,16,20$ and 22) in which relative humidity was high near the ground surface. As mentioned in the previous section, there was less water vapor in two cases (16 and 20 ) of pattern A than in two cases (1 and 22) of pattern $\mathrm{B}$. Their relationship between the mixing ratio of water vapor and temperature gradient $\left(\Delta T\left({ }^{\circ} \mathrm{C}\right) / \Delta Z(\mathrm{mb}) \times 100\right)$ near the ground surface was shown in Fig. 12. Data enclosed by circles show the data at 03.00 LST and the others are the data at $15.00 \mathrm{LST}$. When the value of the temperature gradient is negative and the absolute value is large, it means that a strong inversion layer is formed near the ground. Four (Case 1 (ש)) or five (Cases $16(\mathrm{x}), 20(\bullet)$ and $22(\mathbf{\Delta}))$ sets of data, including the observations at a time of maximum surface pressure, were plotted in each case. In most of observations at 03.00 LST, inversion layers were formed except for Case 1,

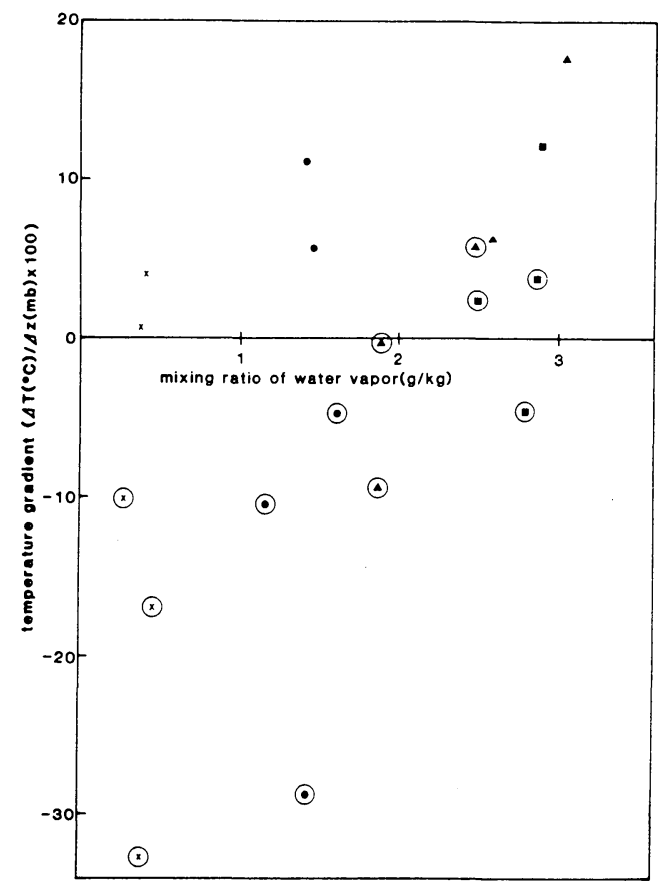

Fig. 12. Relationship between the mixing ratio of water vapor and temperature gradient near the ground surfae. Data enclosed by circles show the data at 03.00 LST and the others are the data at 15.00 LST. Crosses, black circles, black triangles and black squares represent the data in Case 16, Case 20, Case 22 and Case 1, respectively.

and negative temperature gradients were larger in pattern $\mathrm{A}$ than in pattern $\mathrm{B}$. The mixing ratio of water vapor was smaller in pattern $A$ than in pattern B. The mechanism of cloud formation would have been the same for both pattern A and $B$, as described in Section 4. However, clouds in pattern $B$ would have been optically thicker than in pattern A because of the difference in the water vapor content.

\section{Concluding remarks}

The following conclusions on the formation mechanisms of clouds in high-pressure conditions were attained by analyzing mainly the data from upper air sounding. Under high-pressure conditions, it was frequently (over 30\%) overcast at Syowa Station except in December, and a similar tendency can be found at Mizuho Station. Moreover, snowfalls were observed at Syowa Station even under high-pressure conditions and the frequency of these days was rather larger in winter 
than in summer. In many cases of high-pressure a stable layer on an inversion layer was found and some stable layers were around $800 \mathrm{mb}$ level and the others were near the surface.

The stability of the layer between the "base" and the ground surface would have been related to the formation of clouds. That is to say, since water vapor would be preserved in the layer below the "base" because of it being a stable layer, and a cloud would be formed if weak convection was to occur in the layer. After clouds were formed, the gradient of potential temperature became larger and cloud amount increased because of radiative cooling of the cloud-topped layer. Another process of cloud formation is due to the mixing of cold air with moist air. Moreover, surface radiative cooling induced cloud formation. The air temperature that rapidly falls in the early morning near the surface would induce cloud formation and clouds were found to be optically thicker in summer than in winter because of the difference in water vapor content.

This analysis was carried out using the data of Syowa Station, which is a coastal station. Therefore, it is not certain that the characteristic features of clouds described here show the general characteristics in high-pressure conditions in Antarctica. It is necessary to obtain and analyze the aerological data of an inner region, e.g. Mizuho Station and, moreover, detailed observations of clouds and precipitation should be planned by involving meteorological radar, satellites and so on in the future.

\section{Acknowledgement}

The author would like to express sincere thanks to Professor T. Takeda of the Water Research Institute of Nagoya University, for his kind and helpful review of the manuscript. The author is grateful to Professor S. Kawaguchi and Dr. T. Yamanouchi in the National Institute of Polar Research, for valuable insights into the research topic.

\section{References}

Fujiyoshi, Y., T. Takeda and K. Kikuchi, 1982: Observation of wintertime clouds and precipitation in the Arctic Canada (POLEX-North). Part 3: Radar observation of precipitating clouds. J. Meteor. Soc. Japan, $60,1225-1237$.

Japan Meteorological Agency, 1981: Meteorological data at the Syowa Station in1979. Antarctic Meteor. Data, 20, 244 p.

Kato, K., 1982: Oxygen isotopic composition and formation process of snow under anticyclone at Syowa Station, East Antarctica. Memoirs of National Institute of Polar Research, Special Issue, 24, 108-112.

and K. Higuchi, 1979: Oxygen isotopic composition of snow formed under an Antarctic anticyclone. Antarctic Record, 67, 152-163.

- O. Watanabe and K. Satow, 1977: Oxygen isotopic compositon of snow on Mizuho Plateau, Antarctica. Antarctic Record, 58, 263-270. and - 1979: Oxygen isotopic compositon of dirifing snow in Mizuho Plateau, East Antarctica (in Japanese). Antarctic Record, 67, 136-151.

Khrgian, A. Kh., 1977: Structure of stratiform clouds. Izvestiya, Atmospheric and Oceanic Physics, 13, $792-797$.

Kikuchi, K., H. Fukutani and K. Kasahara, 1976: On the cloud height by stereoscopic observation using two fish-eye lens cameras in the summer season at Syowa Station, Antarctica. Antarctic Record, 57, $1-16$.

, S. Tsuboya, N. Sato, Y. Asuma, T. Takeda and Y. Fujiyoshi, 1982: Observation of wintertime clouds and precipitation in the Arctic Canada (POLEX-North). Part 2: Characteristic properties of precipitation particles. J. Meteor. Soc. Japan, 60, 1215-1226.

Lilly, D.K. and W.H. Schubert, 1980: The effect of radiative cooling in a cloud-topped mixed layer. $J$. Atmos. Sci., 37, 482-487.

Loewe, F., 1957: Precipitation and evaporation in the Antarctic. In van Rooy M.P. (editor), Meteorology of the Antarctic. Weather Bureau, South Africa, 7190.

Orvig, S., 1970: Climates of the polar regions. World survey climatology. Vol. 14, Amsterdam, Elsevier Pub. Co., 370 p.

Rusin, N.P., 1961: Meteorological and radiational regime of Antarctica. Jerusalem, Israel Program for Scientific Translations, $1964,355 \mathrm{p}$.

Stephans, G.L., G.W. Paltridge and C.M.R. Platt, 1978: Radiation profiles in extended water clouds III: Observations. J. Atmos. Sci., 35, 2133-2141.

Takeda, T., Y. Fujiyoshi and K. Kikuchi, 1982: Observation of wintertime clouds and precipitation in the Arctic Canada (POLEX-North). Part 1: Characteristic features of clouds and precipitation. J. Meteor. Soc. Japan, 60, 1203-1214. 


\title{
南極沿岸域の高気圧下の雲の形成機構
}

\author{
和田誠 \\ (国立極地研究所)
}

昭和基地の1979年の高層及び地上データまた内陸みずほ基地の地上観測デー夕を解析し，高気圧下に 於ける雲の形成機構について考察した。昭和基地では12月を除いて高気圧下においても，雲量10の時が 30\%以上あった。みずほ基地でも，月による変動があるが雲量10の日数はかなり高かった。更に高気圧 下においても降雪が観測されたこともあった。これらの回数は夏期より冬期に多かつた。高気圧下にお いては，しばしば安定層や逆転層が見られ，それらは，800 mb 付近と雪面（地表面）近くに多く見ら れた。雲の形成, 発達はこれらの安定層と関係していることが多い。解析から示唆されたおもな雲の形 成機構は，安定層の下の弱い対流活動，湿った空気と冷たい空気の混合，そして雪面での放射冷却に起 因する機構であり，発達機構のひとつは雲頂での放射冷却に起因する機構であった。 